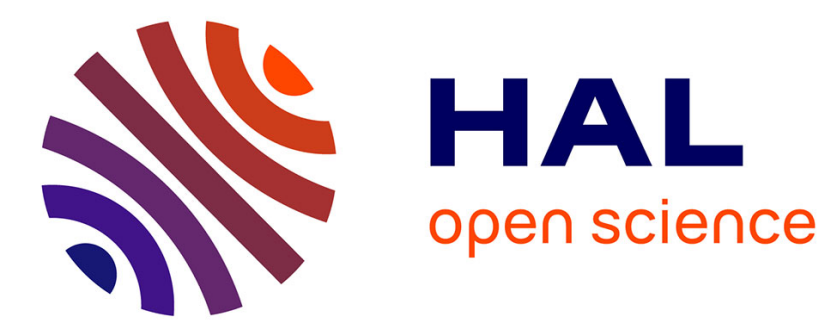

\title{
The tobacco Ext 1.4 extensin gene family is not regulated by auxins in cells proliferating under hormone control
}

Isabelle Salva, Elisabeth Jamet

\section{- To cite this version:}

Isabelle Salva, Elisabeth Jamet. The tobacco Ext 1.4 extensin gene family is not regulated by auxins in cells proliferating under hormone control. BBA - Gene Structure and Expression, 2003, 41, pp.363-367. 10.1016/S0981-9428(03)00031-7 . hal-00157553

\section{HAL Id: hal-00157553 \\ https://hal.science/hal-00157553}

Submitted on 26 Jun 2007

HAL is a multi-disciplinary open access archive for the deposit and dissemination of scientific research documents, whether they are published or not. The documents may come from teaching and research institutions in France or abroad, or from public or private research centers.
L'archive ouverte pluridisciplinaire HAL, est destinée au dépôt et à la diffusion de documents scientifiques de niveau recherche, publiés ou non, émanant des établissements d'enseignement et de recherche français ou étrangers, des laboratoires publics ou privés. 
Published in: Plant Physiol. Biochem. 41 (2003) 363-367.

doi:10.1016/S0981-9428(03)00031-7

The tobacco Ext 1.4 extensin gene family is not regulated by auxins in cells proliferating under hormone control Isabelle Salvà ${ }^{a}$, Elisabeth Jamet ${ }^{\mathrm{a}, \mathrm{b}}$, *

a Institut de Biologie Moléculaire des Plantes (UPR CNRS 2357), 12 rue du Général Zimmer, 67000 Strasbourg, France

b Present address: Signaux Moléculaires et Cellulaires chez les Végétaux (UMR 5546 CNRSUPS), 24 chemin de Borderouge, BP 17 Auzeville, 31326 Castanet Tolosan, France

Corresponding author:

Elisabeth JAMET

Signaux Moléculaires et Cellulaires chez les Végétaux (UMR 5546 CNRS-UPS), 24 chemin de Borderouge, BP 17 Auzeville, 31326 Castanet Tolosan, France

Fax : 33 (0)562 193502

e-mail : jamet@smcv.ups-tlse.fr

*Correspondence and reprints:

Fax : $33(0) 562193502$

e-mail : jamet@smcv.ups-tlse.fr

Abstract - It was previously shown that the tobacco Ext 1.4 extensin gene is expressed in cells proliferating under hormone control and during lateral root initiation. Now, the regulation of expression of the Ext 1.4 gene family is analysed in response to the auxins 2,4dichlorophenoxyacetic acid (2,4-D) and 1-naphthaleneacetic acid (NAA). On the one hand, it is shown that there is no accumulation of Ext 1.4 mRNAs after short periods of incubation of roots or leaf strips in the presence of either 2,4-D or NAA. On the other hand, germination of transgenic seeds carrying the $(-1331 /+46)$ Ext 1.4/3-GUS construct on a 2,4-D containing-medium does not lead to ectopic expression of the chimeric gene. Altogether, these results demonstrate that the genes in Ext 1.4 family are not early auxin-responsive genes. They may be late auxinresponsive genes or their induction in proliferating cells may be the consequence of a higher requirement of structural proteins for the formation of their particular cell walls.

Keywords: Auxin; Cell wall; Extensin; ß-glucuronidase; HRGP; Nicotiana tabacum

Abbreviations: 2,4-D, 2,4-dichlorophenoxyacetic acid; GUS, ß-glucuronidase; HRGP, hydroxyproline-rich glycoprotein; IAA, indole acetic acid; MS, Murashige and Skoog; NAA, 1-naphthaleneacetic acid 


\section{INTRODUCTION}

Plant primary cell walls are composed of polysaccharides, ions and proteins that form a dynamic structure. Numerous genes are involved in the synthesis of cell wall components and in cell wall assembly [3]. Different classes of cell wall structural proteins have been defined: hydroxyprolinerich glycoproteins (HRGP) among which are extensins [14], hydroxyproline/proline-rich proteins (H/PRP) [27], and glycine-rich proteins (GRP) [4]. Cell walls may be modified during development. Cell division is tied in with cell wall formation starting with the elaboration of the cell plate [26]. Elongation requires numerous changes in cell wall composition and structure [17, 19]. Auxin is involved in all these processes by triggering a signal transduction cascade leading to changes in gene expression and /or in specific enzymatic activities related to cell wall metabolism $[1,8,19]$.

We previously showed that the tobacco Ext 1.4 extensin gene is expressed in lateral root primordia [24] which development may be stimulated by the auxin indole acetic acid (IAA) [30]. Ext 1.4 is also expressed in cell proliferating under hormone control either in Agrobacterium tumefaciens-induced stem tumours, in roots or in petioles [11]. We also showed that the Ext 1.4 gene belongs to a small multigene family comprising four members in Nicotiana tabacum [10, 24]. Promoters of these genes comprise two to four motifs very similar to the CTAATTGTTTA motif which was shown to bind in vitro the prha gene product inducible by 2,4dichlorophenoxyacetic acid (2,4-D) [22]. These motifs are respectively located at -48 (TAATTGTTTA), -241 (TAATAGTTTA), -454 (TAATTGTTAT) and -618 (TAATTGTTCT) with respect to the transcription initiation site of Ext 1.4 [Salvà and Jamet, unpublished results]. They were also found in several genes, which are developmentally regulated, pathogen-inducible or auxin-responsive [22]. Altogether, these facts raised the question of the inducibility of Ext 1.4 genes by auxins. The aim of the present study was to analyze the early regulation of the Ext 1.4 gene family by auxins in more details.

\section{RESULTS}

\subsection{The Ext 1.4 gene family is not induced in roots or in leaves in response to auxin}

The aim of the first series of experiments was to test the inducibility of Ext 1.4 genes by auxins (Fig. 1). Two different tissues were used, leaf strips and roots. Auxin treatments were very short as those used for the induction of auxin early-responsive genes [1, 16, 29]. Indeed, analysis of mRNA accumulation was performed after only $2 \mathrm{~h}$ of incubation in the presence of either 2,4-D or 1-naphthaleneacetic acid (NAA). Hybridization to a probe specific for the parA gene, an auxin early-responsive gene, was used as a control for the efficiency of auxin treatment [29]. Indeed, accumulation of parA mRNAs was shown to occur as early as $20 \mathrm{~min}$ after addition of 2,4-D and

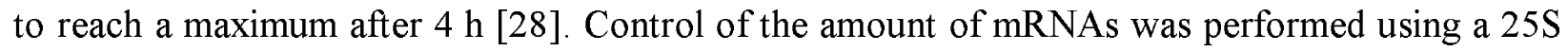
rRNA probe.

As expected, the amount of parA mRNAs strongly increased in leaf strips and in roots after auxin treatment performed either with 2,4-D or NAA (Fig. 1). On the contrary, there was no increase in the level of accumulation of Ext 1.4 mRNAs in response to either auxin treatments (Fig. 1). One $\mathrm{kb}$ Ext $1.4 \mathrm{mRNAs}$ were revealed in leaf strips whereas $1.2 \mathrm{~kb}$ Ext 1.4 mRNAs were found in roots. As previously mentioned Ext 1.4 belongs to a multigene family comprising four genes in N. tabacum Ext 1.4, Ext 1.4B, Ext 1.4C and Ext 1.4D [10, Salvà and Frener, unpublished work]. 
These genes show about $90 \%$ identity in their 3 ' non-coding regions and thus hybridize to the same probe [24]. It means that none of them was induced by auxins in the conditions tested.

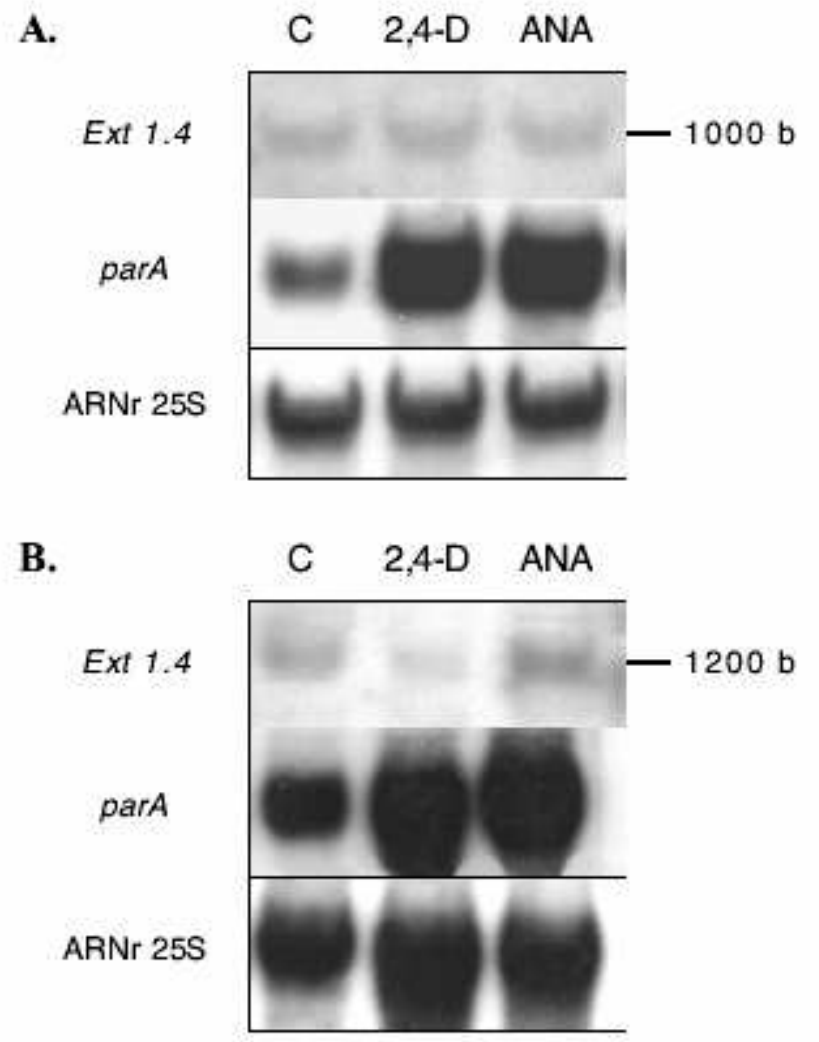

Fig. 1. Accumulation of Ext 1.4 mRNAs in response to auxin treatment. A, leaf strips; B, roots. Leaf strips and roots were treated as described in Methods. Total RNAs were extracted from control leaf strips or roots (C), or from leaf strips or roots incubated for $2 \mathrm{~h}$ in $10 \mathrm{mg} . \mathrm{L}^{-1} 2,4-\mathrm{D}$ or NAA. RNA gel blots were performed with $5 \mu \mathrm{g}$ RNAs per sample. Hybridizations were successively performed on the same membrane with a probe spanning the 3' non-coding region of Ext 1.4, a parA probe and a $25 \mathrm{~S}$ rRNA probe. Membranes were over-exposed after hybridization to the Ext 1.4 probe.

\subsection{Expression of the $(-1331 /+46)$ Ext $1.4 / \mathrm{B}$-GUS chimeric gene in seeds germinating in the presence of auxin}

The Ext 1.4 gene was chosen for the second series of experiments since its promoter comprises four putative auxin-regulatory elements. Transgenic seeds carrying the $(-1331 /+46) E x t 1.4 / \beta-$ GUS chimeric gene were sowed on different media supplemented or not with 2,4-D as previously described [22]. These experiments were performed with 6 independent transgenic lines carrying the $(-1331 /+46)$ Ext 1.4/ß-GUS construct. Histochemical analyses were performed at different times after beginning of germination. In control plantlets, cotyledons were fully developed after 8 days (Fig. 2B). As expected [23], in plantlets grown on 2,4-D containing-medium, growth was 
delayed by about $4 \mathrm{~d}$ whereas inhibition of root elongation was observed (compare Fig. 2A-B to Fig. 2C-D).

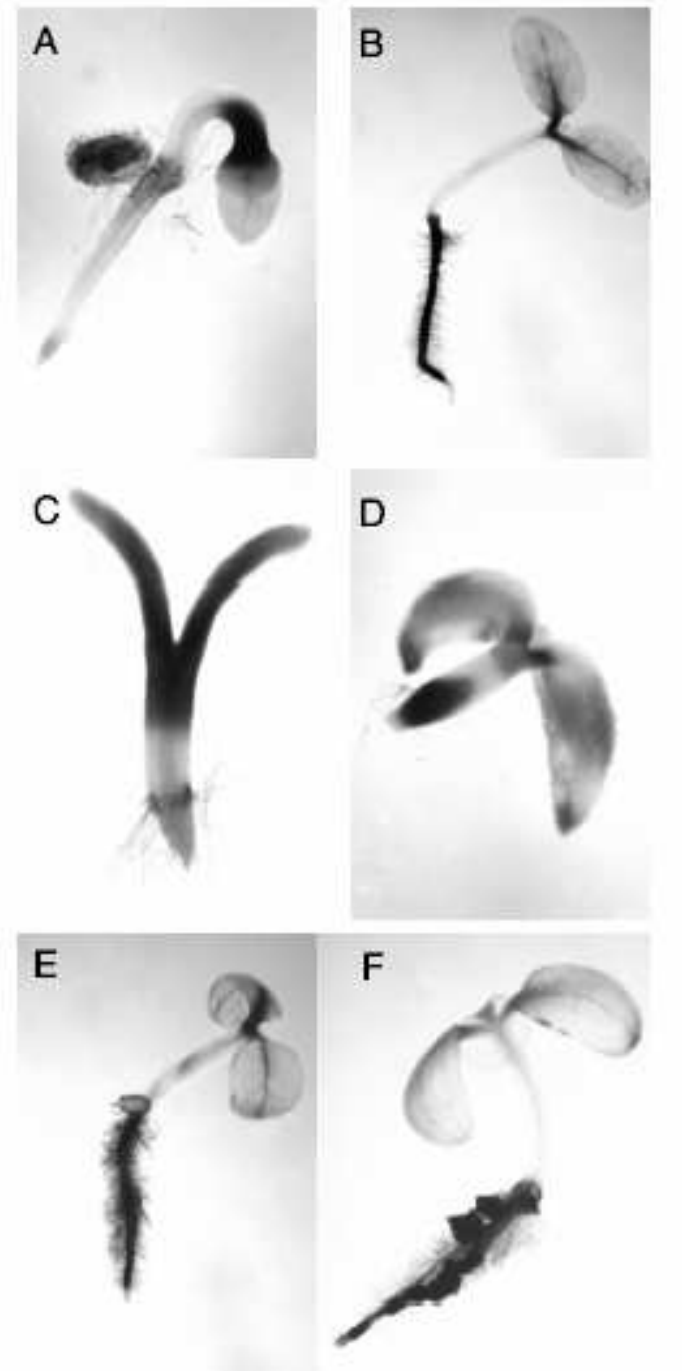

Fig. 2. Influence of 2,4-D on the expression of the chimeric $(-1331 /+46) E x t 1.4 / ß-$ GUS gene during germination. A, B, control plantlets were analyzed 6 or 8 days respectively after sowing on MS medium modified as described in Methods; C, D, plantlets were analyzed 10 or 12 days respectively after sowing on modified MS medium supplemented with $1 \mathrm{mg} . \mathrm{L}^{-1} 2,4-\mathrm{D}$. E, F, plantlets were grown on modified MS medium for $7 \mathrm{~d}$, and then analyzed 1 or $7 \mathrm{~d}$ after transfer on modified MS medium supplemented with $1 \mathrm{mg} . \mathrm{L}^{-1}$ 2,4-D. GUS activity was revealed by in situ staining.

In control plantlets, after $6 \mathrm{~d}$ of germination, the $(-1331 /+46)$ Ext $1.4 /$ B-GUS chimeric gene was found to be expressed in collar cells and in the hypocotyl hook (Fig. 2A). Eight days after the beginning of germination, GUS staining was observed in the root piliferous zone, at the cotyledon bases and sometimes in cotyledons (Fig. 2B). GUS staining in the root was more precisely located in epidermis and hairs as previously shown [11]. In plantlets grown on 2,4-D containing-medium, 
despite the differences observed in morphology, there was no significant difference in the pattern of expression of the (-1331/+46)Ext 1.4/ß-GUS chimeric gene in root and in hypocotyl (Fig. 2CD). The expression in cotyledons may have occurred at a slightly higher level.

Finally, plantlets grown on a medium lacking 2,4-D during $7 \mathrm{~d}$ were transferred to a 2,4-D containing medium and analyzed after 1 day (Fig. 2E) or $7 \mathrm{~d}$ (Fig. 2F). After $1 \mathrm{~d}$, both the number and length of root hairs increased [21]. The pattern of expression of the $(-1331 /+46) E x t 1.4 / 3-$ GUS chimeric gene was not modified (compare Fig 2E and Fig. 2B). After 7 d, GUS staining was found in the numerous root primordia induced by 2,4-D (Fig. 1F).

All these experiments show that it was not possible to induce any ectopic expression of the $(-1331 /+46)$ Ext 1.4/ß-GUS chimeric gene in 2,4-D treated-plantlets within a short time. GUS staining was only found in cells induced to proliferate upon auxin treatment.

\section{DISCUSSION}

Altogether, these results show that Ext 1.4 genes are not directly inducible by auxins even if they are expressed in cells proliferating upon hormone control and if several putative auxin-regulatory elements are present in their promoters. Ext 1.4 transcripts do not accumulate in leaf strips or in roots after a short auxin treatment as described in the case of typical auxin-inducible genes [16, 28]. The only modification of the pattern of expression of the $(-1331 /+46)$ Ext $1.4 /$ / -GUS chimeric gene is found in cotyledons. But, this may be due to the fact that the development of plantlets is delayed after auxin treatment. The time of emergence of the plantlet out of the seed is much longer. This causes additional mechanical constraints that are known to induce the expression of Ext 1.4 genes [24]. However, the expression of the $(-1331 /+46)$ Ext 1.4/ß-GUS chimeric gene was not found in all plantlet tissues as shown in the case of the prha gene, a true auxin early-responsive gene [22]. Thus, Ext 1.4 genes do not belong to auxin early-responsive genes. In contrast, the Medicago sativa MsPRP5 gene encoding a PRP is induced by 2,4-D in cell suspension cultures as early as 20 min after commencing treatment [9]. The $N$. tabacum HRGPnt 3 gene encoding a protein with a C-terminal extensin domain is induced in newly-formed root primordia 2 to $6 \mathrm{~h}$ after the beginning of IAA treatment [31].

Ext 1.4 genes may belong to late-responsive genes, as may other genes encoding cell wall structural proteins. The carrot $D c P R P I$ gene encoding a proline-rich protein was not found to be induced $3 \mathrm{~h}$ after IAA, NAA or 2,4-D application, but was expressed at a high level $24 \mathrm{~h}$ after one of these treatments [5]. The Arabidopsis thaliana proline-rich protein gene AtPRP3 is expressed in root hairs and its level of expression is greatly induced $48 \mathrm{~h}$ after NAA treatment [2].

Alternatively, the expression of Ext 1.4 genes in cell proliferating under hormone control may due to the necessity for high level production of extensins. Indeed, usually these cells form calli and they are not organized in tissues. Their cell walls have a particular structure which was shown to have a high content in hydroxyproline [32].

Finally, it seems that there is no general rule for the regulation of expression of genes encoding cell wall structural proteins in response to auxins. Same conclusions could be drawn for other types of regulation of such genes, such as responses to wounding or mechanical constraints [12]. This may be related to the fact that the proteins they encode confer different properties to cell walls. 


\section{METHODS}

\subsection{Plant material}

Seeds of Nicotiana tabacum L. var Samsun were provided by SEITA (Institut Expérimental du Tabac). Plants of N. tabacum L. var. Petit Havana SR1 [15] were used for Agrobacterium tumefaciens-mediated transformations. Greenhouse culture conditions were a $16 \mathrm{~h} \mathrm{light} / 8 \mathrm{~h}$ dark cycle at $22 \pm 4^{\circ} \mathrm{C}$. In vitro culture conditions were a $16 \mathrm{~h}$ light $\left(24^{\circ} \mathrm{C}\right) / 8 \mathrm{~h}$ dark $\left(20^{\circ} \mathrm{C}\right)$ cycle.

\subsection{RNA analysis}

Isolation of total RNAs was performed according to [7]. Northern blot analyses were performed as described in [20]. A fragment spanning the 3' non-coding region of the Ext 1.4 gene was used as a probe specific for the Ext 1.4 gene family [24]. A probe specific for the $N$. tabacum parA gene was a gift from Prof. T. Nagata [28]. The integrity and the amount of RNAs were systematically checked using a bell pepper $25 \mathrm{~S}$ rRNA probe kindly provided by Dr. R. Schantz (IBMP-CNRS Strasbourg). All these probes were labeled with $[\alpha-32 \mathrm{P}] \mathrm{dCTP}(3000 \mathrm{Ci} / \mathrm{mmol}$, Amersham Pharmacia Biotech UK Limited) by random priming [6].

\subsection{Chimeric gene construct and plant transformation}

DNA manipulations were performed according to standard procedures [25]. The (1331/+46)Ext 1.4/ß-glucuronidase (GUS) construct was previously described [11]. Leaf discs of N. tabacum L. var Petit Havana SR1 were transformed using A. tumefaciens LBA4404 as previously described [11]. Transgenic plantlets were grown in vitro.

\subsection{Auxin treatments}

Leaf strips and roots of in vitro-grown plantlets were successively incubated during $4 \mathrm{~h}$ in a Murashige and Skoog (MS) medium diluted [18], and during $2 \mathrm{~h}$ in fresh MS medium either in the absence of auxin or in the presence of $10 \mathrm{mg} . \mathrm{L}^{-1} 2,4-\mathrm{D}$ or $10 \mathrm{mg} . \mathrm{L}^{-1}$ NAA. During the incubation, samples were gently shaken at $24{ }^{\circ} \mathrm{C}$. Seeds of transgenic plants were obtained by selfpollination of primary transformants. They were sown on modified MS medium containing 10 g. $\mathrm{L}^{-1}$ sucrose and $300 \mathrm{mg} . \mathrm{L}^{-1}$ kanamycin. This germination medium was eventually supplemented with $1 \mathrm{mg} . \mathrm{L}^{-1} 2,4-\mathrm{D}$. Histochemical analysis of GUS activity was performed as described in [13].

Acknowledgements. We wish to thank Prof. T. Nagata and Dr. R. Schantz for the gift of probes. We acknowledge P. Keltz and R. Wagner for taking care of the plants. This work was supported by CNRS and by a grant from "Ministère de l'Education Nationale, de la Recherche et de la Technologie" to I.S. 


\section{REFERENCES}

[1] Abel S., Theologis A., Early genes and auxin action, Plant Physiol. 111 (1996) 9-17.

[2] Bernhardt C., Tierney M.L., Expression of AtPRP3, a proline-rich structural cell wall protein from Arabidopsis, is regulated by cell-type-specific development pathways involved in root hair formation, Plant Physiol. 122 (2000) 705-714.

[3] Carpita N., Tierney M., Campbell M., Molecular biology of the plant cell wall: searching for the genes that define structure, architecture and dynamics, Plant Mol. Biol. 47 (2001) 1-5.

[4] Condit C.M., Keller B., The glycine-rich cell wall proteins of higher plants in: Adair W.S., Mecham R.P. (Eds), Organization and Assembly of Plant and Animal Extracellular Matrix, Academic Press Inc., San Diego, 1990, pp. 195-291.

[5] Ebener W., Fowler T.J., Susuki H., Shaver J., Tierney M.L., Expression of DcPRP1 is linked to carrot storage root formation and is induced by wounding and auxin treatment, Plant Physiol. 101 (1993) 259-265.

[6] Feinberg A.P., Vogelstein B., A technique for radiolabelling DNA restriction endonuclease fragments to high specific activity, Anal. Biochem. 132 (1983) 6-13.

[7] Goodall G.J., Wiebauer K., Filipowicz W., Analysis of pre-mRNA processing in transfected protoplasts, Meth. Enzymol. 88 (1990) 148-151.

[8] Guilfoyle T., Hagen G., Ulmasov T., Murfett J., How does auxin turn on genes, Plant Physiol. 111 (1998) 341-347.

[9] Györgyey J., Németh K., Magyar Z., Kelemen Z., Alliotte T., Inzé D., Dudits D., Expression of a novel-type small proline-rich protein gene of alfalfa is induced by 2,4-D dichlorophenoxyacetic acid in dedifferentiated callus cells, Plant Mol. Biol. 34 (1997) 593-602.

[10] Hirsinger C., Parmentier Y., Durr A., Fleck J., Jamet E., Characterization of a tobacco extensin gene and regulation of its gene family in healthy plants and under various stress conditions, Plant Mol. Biol. 33 (1997) 279-289.

[11] Hirsinger C., Salvà I., Marbach J., Durr A., Fleck J., Jamet E., The tobacco extensin gene Ext 1.4 is expressed in cells submitted to mechanical constraints and in cells proliferating under hormone control, J. Exp. Bot. 50 (1999) 343-355.

[12] Jamet E., Guzzardi P., Salvà I., What do transgenic plants tell us about the regulation and function of cell-wall structural proteins like extensins? Rus. J. Plant Physiol. Engl. Tr. 47 (2000) 318-326.

[13] Jefferson R.A., Assaying chimeric genes in plants: the GUS gene fusion system, Plant Mol. Biol. Rep. 5 (1987) 387-405.

[14] Kieliszewski M.J., Lamport D.T.A., Extensin: repetitive motifs, functional sites, posttranslational codes, and phylogeny, Plant J. 5 (1994) 157-172.

[15] Maliga P., Breznovits A.S., Marton L., Streptomycin-resistant plants from callus culture of haploid tobacco, Nature New Biol. 244 (1973) 29-30.

[16] McClure B.A., Guilfoyle T., Characterization of a class of small auxin-inducible soybean polyadenylated RNAs, Plant Mol. Biol. 9 (1987) 611-623.

[17] McQueen-Mason S.J., Expansins and cell wall expansion, J. Exp. Bot. 46 (1995) 1639-1650.

[18] Murashige T., Skoog F., A revised medium for rapid growth and bioassays with tobacco tissue culture, Physiol. Plant. 15 (1962) 473-497.

[19] Nicol F., Höfte H., Plant cell expansion: scaling the wall, Cur. Opin. Plant Biol. 1 (1998) 1217.

[20] Parmentier Y., Durr A., Marbach J., Hirsinger C., Criqui M.C., Fleck J., Jamet E., A novel wound-inducible extensin gene is expressed in newly isolated protoplasts of Nicotiana sylvestris, Plant Mol. Biol. 29 (1995) 279-292.

[21] Pitts R.J., Cernac A., Estelle M., Auxin and ethylene promote root hair elongation in Arabidopsis, Plant J. 16 (1998) 553-560. 
[22] Plesch G., Störmann K., Tovar Torres J., Walden R., Somssich I.E., Development and auxininduced expression or the Arabidopsis prha homeobox gene, Plant J. 12 (1997) 635-647.

[23] Sachs T., The control of the patterned differentiation of vascular tissue, Adv. Bot. Res. 3 (1981) 151-262.

[24] Salvà I., Jamet E., Expression of the tobacco Ext 1.4 extensin gene upon mechanical constraints and localization of regulatory regions. Plant Biol. 3 (2001) 1-10.

[25] Sambrook J., Fritsch E.F., Maniatis T., Molecular Cloning: A Laboratory Manual, 2nd edn. Cold Spring Harbor Laboratory Press, Cold Spring Harbor, NY, 1989.

[26] Samuels A.L., Giddings TH Jr, Staehelin L.A., Cytokinesis in tobacco BY-2 and root tip cells: a new model of cell plate formation in higher plants, J. Cell Biol. 130 (1995) 1345-1357.

[27] Showalter A.M., Structure and function of plant cell wall proteins, Plant Cell 5 (1993) 9-23.

[28] Takahashi Y., Kusaba M., Hiraoka Y., Nagata T., Characterization of the auxin-regulated par gene from tobacco mesophyll protoplasts, Plant J. 1 (1991) 327-332.

[29] Takahashi Y., Niwa Y., Machida Y., Nagata T., Location of the cis-acting auxin-responsive region in the promoter of the par gene from tobacco mesophyll protoplasts, Proc. Natl. Acad. Sci. USA 87 (1990) 8013-8016.

[30] Torrey J.G., The induction of lateral roots by indoleacetic acid and root decapitation, Am. J. Bot. 37 (1950) 257-264.

[31] Vera P., Lamb C., Doerner P.W., Cell-cycle regulation of hydroxyproline-rich glycoprotein HRGPnt3 gene expression during the initiation of lateral root meristem, Plant J. 6 (1994) 717727.

[32] L.G. Wilson, J.C. Fry, Extensin - a major cell wall glycoprotein, Plant Cell Environ. 9 (1986) 239-260. 